\title{
INCREASING THE EFFICIENCY OF SULFUR DIOXIDE IN WINE BY USING OF SATURATED HIGHER FATTY ACIDS
}

\author{
P. Bábíková, M. Baroň, M. Kumšta, R. Sotolář
}

Received: April 5, 2011

\begin{abstract}
BÁBÍKOVÁ, P., BAROŇ, M., KUMŠTA, M., SOTOLÁŘ, R.: Increasing the efficiency of sulphur dioxide in wine by using of saturated higher fatty acids. Acta univ. agric. et silvic. Mendel. Brun., 2012, LX, No. 1, pp. 17-22

This work is aimed on stopping of alcoholic fermentation to leave residual sugar and the possibility of sulfur dioxide reduction in wine technology and storage. As a very good opportunity showed mixture of higher saturated fatty acids with a reduced dose of sulfur dioxide. Experiments have confirmed that the concentration of viable yeasts in $1 \mathrm{ml}$ of wine for variants treated with a mixture of fatty acids is significantly lower than in variants treated with sulfur dioxide alone. Then was monitored the influence of fatty acids on stored wine with residual sugar. At this point a dramatically prolongation of interval to secondary fermentation (depreciation of wine) in the bottle was confirmed. Finally, attention was paid to influence on the organoleptic characteristics of wine treated this way. In this case, it is possible to consider the recommended concentration of fatty acid below the threshold of susceptibility.
\end{abstract}

yeasts inhibition, octanoic acid, decanoic acid, Saccharomyces cerevisiae, toxicity, ethanol

The issue of early stopping of alcoholic fermentation in order to leave residual sugar in wine is very complicated. Current methods using in practice, such as cooling and filtration, leading to increasing costs and are undoubtedly very laborious and, moreover, especially for home winemakers unavailable. Separate application of sulfur dioxide is not always wholly reliable, and at high concentrations it leads to quality reduction of future products - wines.

Octanoic - caprylic acid $\left(\mathrm{C}_{8}\right)$, decanoic - capric acid $\left(\mathrm{C}_{10}\right)$ and dodecanoic - lauric acid $\left(\mathrm{C}_{12}\right)$ belongs to a group of higher monocarboxylic saturated fatty acids that occur naturally walnut or breast milk. These acids are industrially used for the manufacture of dyes or perfumes. In oenology were studied for their inhibitory effect on alcoholic and malolactic fermentation many years ago (LAure et al., 1986; De Felice et al., 1993). Some of the higher fatty acids $\left(\mathrm{C}_{16}\right.$ and $\left.\mathrm{C}_{18}\right)$ are fermentation activators. On the contrary, other fatty acids with shorter chain, in particular acids, $\mathrm{C}_{6}, \mathrm{C}_{8}$ and $\mathrm{C}_{10}$ have fungicidal properties (GENEIX et al., 1983; VIEGAs et al.,
1995; VIEgAs et al., 1991). They are made by yeasts themselves during alcoholic fermentation and may contribute to its difficulties in completing the course (SÁ-CorreIA et al., 1986). The increased concentration very often accompanied with problems during alcoholic fermentation. These properties combined with a complete wholesomeness led to the idea that it could serve as a substitution or complementation of sulfur dioxide to wine stabilization.

It offers so many possibilities for their use, but the total concentration added to the wine should not exceed $10 \mathrm{mg} / \mathrm{l}$. The concentration of fatty acids has fungicidal effect and complements use of sulfur dioxide. E.g. for stopping the alcoholic fermentation of sweet wine, $150 \mathrm{mg}$ of $\mathrm{SO}_{2}+9 \mathrm{mg}$ per liter of fatty acids is as effective as $250 \mathrm{mg}$ of $\mathrm{SO}_{2}$ per liter alone. Savings and efficiency of $\mathrm{SO}_{2}$ is significant. Fatty acids should be added 24 hours before distribution. Under these conditions, $\mathrm{SO}_{2}$ causes most (if not complete) inactivation (LAURE et al., 1986).

The big advantage of this approach is that fatty acids added to wine are absorbed and assimilated by yeasts cells and little is esterified. In fact, studies 
comparing the composition of fatty acids and their esters in wine treated and untreated with fatty acids showed that the concentrations remained within the normal range from 2.6 to $12.4 \mathrm{mg} / \mathrm{l}$ (fatty acids) and from 0.2 to $0.81 \mathrm{mg} / \mathrm{l}$ (ethyl esters), without any increase in the concentration of volatile compounds (VIEGAs et al., 1989). The proportion of fatty acids is eliminated by fixation on the bodies of dead yeasts cells. After such treatments, sweet wines can be preserved with $40 \mathrm{mg} / \mathrm{l}$ of free $\mathrm{SO}_{2}$ concentration. It should be noted that fatty acids are more effective than sorbic acid, which does not decrease the concentration of $\mathrm{SO}_{2}$ used to stop fermentation.

This inhibitory effect inversely correlated with $\mathrm{pH}$ in the environment in the range 3.0 to 5.4 (VIEGAS et al., 1997). This discovery induces the idea that inhibition is caused by their undissociated form (AleXANDre et al., 1996). Moreover, it was found that doses sufficient to inhibit varies with the tested type of yeast e.g. Kluyveromyces marxianus (E. C. Hansen) are less sensitive than Saccharomyces cerevisiae (E. C. Hansen) (SÁ-CORREIA et al., 1986). The mechanism of this inhibition is not yet fully understood. The most probably theory is the passive diffusion of fatty acids through the plasma membrane of yeasts, which are like as undissociated molecules dissolved in a phospholipids membrane and deactivate other lipid-lipid and lipid-protein interactions, resulting in a fatal modification of a specific arrangement of the membrane. This modification represents an increase in the permeability and the subsequent change in the production of enzymes and transport systems. Such affected yeasts are unable to continue to convert glucose into ethanol, followed by their death.

Although the $\mathrm{C}_{10}$ is more toxic than $\mathrm{C}_{8}, \mathrm{C}_{10}$ toxicity is actually lower than was predicted because of its lower solubility. The explanation for this phenomenon is that lipid-soluble substances with a size larger than certain critical chain length may be considered as less toxic to the plasma membrane than smaller molecules. Moreover, at low concentrations of have fatty acids with longer chains tendency to clot formation (LAFON-LAFOURCADE et al., 1984).

GENEIX et al. (1983) showed that a combination of $\mathrm{C}_{6}, \mathrm{C}_{8}$ and $\mathrm{C}_{10}$ addition at a dose of $3 \mathrm{mg} / \mathrm{l}$ each of them achieves rapid suppression of yeasts. The combination is actually more toxic than the same addition of any acid separately. In four days concentration decreased from $8 \times 10^{6}$ to $4 \times 10^{4}$ cells per $\mathrm{ml}$. And degradation of sugars was totally stopped. Only after a few weeks of leaving, the yeasts population increased again and began to ferment. This delay in function of yeasts is probably due to their adaptation and especially esterification of fatty acids. Esters are known to have much lower inhibitory effect than the acids from which they were derived.

Higher fatty acids are currently not used to inhibit the activity of yeasts during alcoholic fermentation and lactic acid bacteria during fermentation. Published works demonstrate the properties of higher fatty acids. However, they did not compare the effectiveness of these compounds and the development of wine treated this way in the context of sulfur dioxide and the possibility of restart fermentation (secondary fermentation). Most experiments were performed in synthetic media, not in musts or wines. Moreover, in small volumes unrealistic in practice.

\section{MATERIALS AND METHODS}

\section{Wine}

Used wine to determine the effect of higher fatty acids on the secondary fermentation: wine from interspecific variety 'Malverina', $\mathrm{pH}=3.22$, $18 \mathrm{~g} / \mathrm{l}$ residual sugar, free $\mathrm{SO}_{2} 28.4 \mathrm{mg} / \mathrm{l}$, total $\mathrm{SO}_{2}$ $162.8 \mathrm{mg} / \mathrm{l}$, sterile unfiltered.

Application of higher fatty acids, $\mathrm{C}_{8}-3 \mathrm{mg} / \mathrm{l}, \mathrm{C}_{10}$ $-6 \mathrm{mg} / \mathrm{l}$ was carried out at the stage of 10-15 g/l of residual sugar in media. After the 24 hours was added sulfur dioxide into all variants. Sampling was carried out on agar after 3 days.

Within nine bottles was added a mixture of higher fatty acids concentrations 1, 2, 3, 4, 5, 6, 16, 30 and $80 \mathrm{mg} / \mathrm{l}\left(\mathrm{C}_{8} / \mathrm{C}_{10}-2: 3\right)$ one variant served as a control. The bottles were closed only with temporary plastic cap and stored at room temperature in order to support starting of secondary fermentation. As a detection of secondary fermentation in the bottle was used sensory testing and controlling of carbon dioxide production. Date of starting secondary fermentation is the average of two bottles rounded to the day. While the control sample yielded a secondary fermentation after ten days, a sample of real addition of higher fatty acids $6 \mathrm{mg} / \mathrm{l}$ resisted several times longer.

\section{Effect of fatty acids and sulfur dioxide}

Tracking the number of live microorganisms was done by the method of inoculation by dressing of sterile Petri dish with a diameter of $90 \mathrm{~mm}$. Inoculum volume was $1 \mathrm{ml}$. The sample was removed with sterile pipette. Was maintained constant height system - half of the bottle. Used medium was malt agar from the company Imuna. Inoculation was done in a sterile environment laminar box. Each sample was inoculated on 3 Petri dishes during each experiment the sterility of environment and sterility of broth was checked.

Samples were incubated in a thermostat at $24^{\circ} \mathrm{C}$ and after 5 days was determined number of colonies on dishes.

\section{Sulfur dioxide}

Determination of sulfur dioxide was made by titration with standard iodine solution. The standard solution of iodine oxidizes directly free sulfur dioxide contained in the wine or the bonded sulfur dioxide released from carbonyl compounds in an alkaline environment. 
Free sulfur dioxide:

In $250 \mathrm{ml}$ conical flask add $50 \mathrm{ml}$ of wine tested by pipette still touch the bottom of the flask. Immediately add $10 \mathrm{ml} 16 \% \mathrm{H}_{2} \mathrm{SO}_{4}$ and about $5 \mathrm{ml}$ of $0.5 \%$ starch wax and immediately titrate $0.02 \mathrm{M}$ solution of iodine to a blue color, which lasts 30 seconds.

Total sulfur dioxide:

In $250 \mathrm{ml}$ conical flask add $25 \mathrm{ml} 1 \mathrm{M} \mathrm{NaOH}$ and $50 \mathrm{ml}$ of wine tested by pipette still touch the bottom of the flask. After 15 minutes standing add $15 \mathrm{ml}$ $16 \% \mathrm{H}_{2} \mathrm{SO}_{4}$ and about $5 \mathrm{ml}$ of $0.5 \%$ starch wax and immediately titrated with $0.02 \mathrm{M}$ solution of iodine to a blue color, which lasts 30 seconds.

\section{Tasting panel}

After the analysis has been conducted sensory evaluation of wines. Tasting panel consisted of seven assessors, all assessors with CAFIA (Czech
Agriculture and Food Inspection Authority) wine tasting certificate.

Threshold was defined as the level at which the spiked sample could be distinguished $50 \%$ of the time over chance.

\section{RESULTS AND DISCUSSION}

To compare the efficiency of higher fatty acids were selected 10 fermenting grape musts in the volumes of 50-5 000 liters. Application of higher fatty acids, $\mathrm{C}_{8}-3 \mathrm{mg} / \mathrm{l}, \mathrm{C}_{10}-6 \mathrm{mg} / \mathrm{l}$ was carried out at the stage of 10-15 g/l of residual sugar in media. After the 24 hours was added sulfur dioxide into all variants. Sampling was carried out on agar after 3 days. The measurement results confirm the effective reduction of viable populations of yeasts in the variants with combined use of higher fatty acids and sulfur dioxide, see Tab. I.

I: Viable yeasts in $1 \mathrm{ml}$ of wine with and without a mixture addition of higher fatty acids complement the $\mathrm{SO}_{2}$ to stop fermentation at the stage of $10-15 \mathrm{~g} / \mathrm{l}$ residual sugar

\begin{tabular}{cccccc}
\hline Sample & Fattyacids & $\begin{array}{c}\text { Volume } \\
{[\mathbf{l}]}\end{array}$ & $\begin{array}{c}\text { Total SO } \\
{[\mathbf{m g} / \mathbf{l}]}\end{array}$ & $\begin{array}{c}\text { Free SO } \\
{[\mathbf{m g} / \mathbf{l}]}\end{array}$ & $\begin{array}{c}\text { Yeasts population } \\
{[\mathbf{1} / \mathbf{m l}]}\end{array}$ \\
\hline 1 & Yes & 350 & 107.6 & 60.7 & $10^{2}$ \\
2 & Yes & 350 & 113.9 & 45.6 & $10^{2}$ \\
3 & Yes & 350 & 91.1 & 51.9 & $10^{0}$ \\
4 & Yes & 5000 & 184.7 & 65.8 & $10^{1}$ \\
5 & Yes & 5000 & 165.8 & 32.9 & $10^{2}$ \\
6 & No & 50 & 170.8 & 84.8 & $>10^{4}$ \\
7 & No & 50 & 130.3 & 45.6 & $>10^{4}$ \\
8 & No & 150 & 120.2 & 50.6 & $10^{3}$ \\
9 & No & 100 & 79.7 & 17.7 & $>10^{4}$ \\
10 & No & 100 & 73.4 & 24.0 & $10^{3}$ \\
\hline
\end{tabular}

Note: The values of $\mathrm{SO}_{2}$ are measured by iodometric determination including ascorbic acid and reductons, yeasts population is calculated by multiplication on agar.

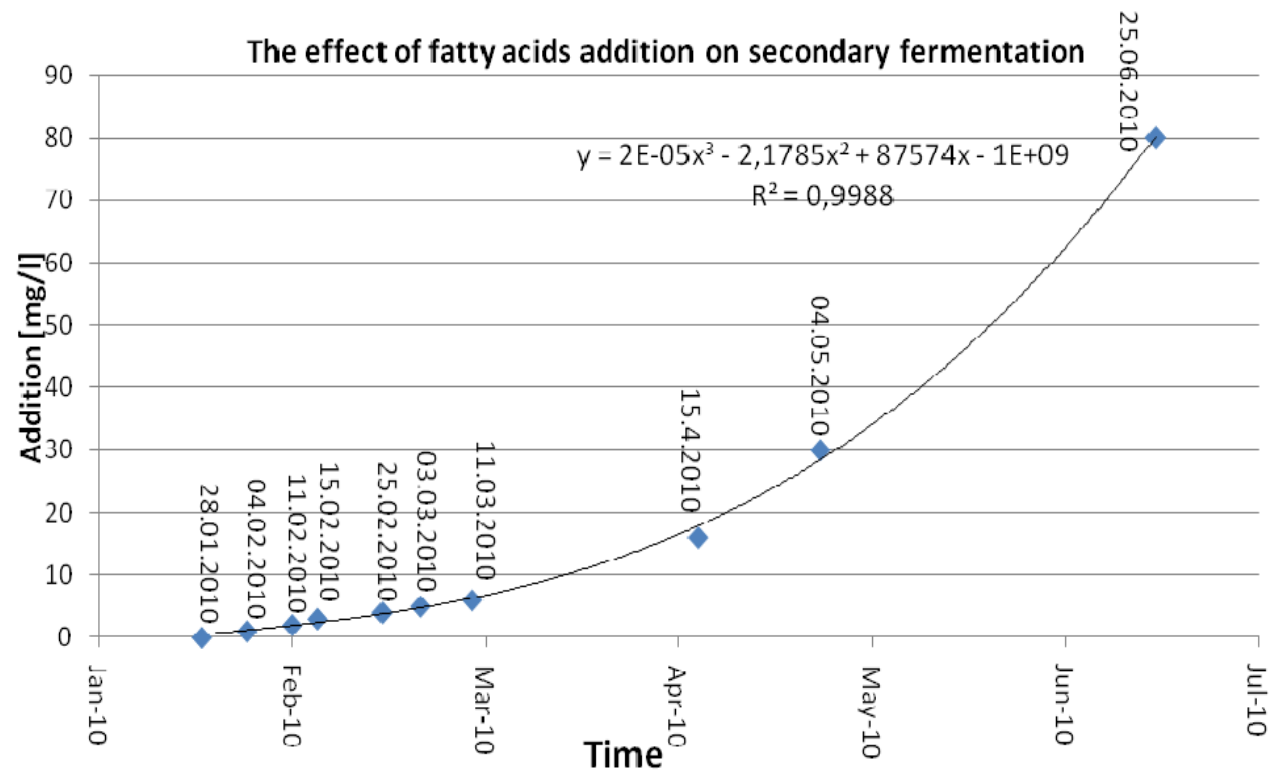

1: Effect of added higher fatty acids to the delay of secondary fermentation 
To determine the effect of higher fatty acids on the secondary fermentation was selected wine (see Materials) divided into ten variants. Date of starting secondary fermentation is the average of two bottles rounded to the day. The results obtained (see Fig. 1) demonstrate the inhibitory effect of higher fatty acids for yeasts initiating secondary fermentation. While the control sample yielded a secondary fermentation after ten days, a sample of real addition of higher fatty acids $6 \mathrm{mg} / \mathrm{l}$ resisted several times longer. Especially, the $28^{\text {th }}$ of January 2010 in case of no added and $11^{\text {th }}$ of March 2010 for additional 6 $\mathrm{mg} / \mathrm{l}$ of a fatty acids mixture. Subsequently, the data fit the polynomial regression of the third degree with $\mathrm{R}^{2}=0.9988$. Addition of higher fatty acids dramatically reduces the need for sulfur dioxide in stored and bottled wines with residual sugar.

Since a large portion of fatty acids are fixed to the yeasts cells after application and consequently eliminated during clarification the organoleptic properties wines treated this way is negatively affecting (RIBÉREAU-GAYON et al., 2006). To determine the effect on the organoleptic properties of the finished wine the sensory test was conducted with increasing addition of a mixture of higher fatty acids. As a matrix for all variants the same wine was used (see Material). Tasting panel consisted of seven members was first explicitly advised with the clear smell and taste of the higher fatty acids mixture (often described as a soap, paraffin, rancid fat, wet skin or cellulose). Then they were tested for proportionally increasing of $\mathrm{C}_{8}-3 \mathrm{mg} / \mathrm{l} \mathrm{C}_{10}-6 \mathrm{mg} / \mathrm{l}$ concentration in the wine. Results are described in Table II.

Subsequently were the same samples shuffled and evaluated in random order, the results in Tab. III.

Obtained results show that the addition of higher fatty acids mixture can be in evaluated wine reliably detect from the concentration of $30 \mathrm{mg} / \mathrm{l}$. In other words, the concentration $6 \mathrm{mg} / \mathrm{l}$ is below the threshold of trained individual's perceptibility and concentrations under $16 \mathrm{mg} / \mathrm{l}$ were identified less than $50 \%$ of the time over the chance of a tip (see Methods).

Optimized properties to inhibit yeasts and lactic acid bacteria with the current potential for treatment of wine against secondary fermentation is likely to offer a mixture of higher fatty acids $\mathrm{C}_{8}, \mathrm{C}_{10}$ and $\mathrm{C}_{12}$ dissolved in $70 \%$ vol. ethanol, with $100 \mathrm{ml}$ ethanol solution containing $10 \mathrm{~g}$ of this mixture. Such a mixture is prepared in a liquid state and there is unlikely to solid phase at low temperatures, which makes it very easy to dose it practice. The advantage of the proposed mix is high fungicidal activity of $\mathrm{C}_{8}$ and $\mathrm{C}_{10}, \mathrm{C}_{12}$ acids, and the maximum toxicity against lactic acid bacteria (data not show). Secondary purpose of $\mathrm{C}_{8}$ acid is to increase the solubility of difficult soluble $\mathrm{C}_{12}$ acid. Using fatty acids with chain lengths above 12 carbons are also already irrelevant, since have a significant decrease of solubility in

II: Sensitivity of the wine assessors on increasing addition of higher fatty acids in wine

\begin{tabular}{|c|c|c|c|c|c|c|c|c|}
\hline \multirow{2}{*}{$\begin{array}{c}\begin{array}{c}\text { Addition } \\
{[\mathrm{mg} / \mathrm{l}]}\end{array} \\
1\end{array}$} & \multicolumn{7}{|c|}{ Sensitivity of assessors } & \multirow{2}{*}{$\begin{array}{c}\begin{array}{c}\text { Response } \\
{[\%]}\end{array} \\
0\end{array}$} \\
\hline & No & No & No & No & No & No & No & \\
\hline 3 & No & No & No & No & No & No & No & 0 \\
\hline 4 & No & No & No & No & No & No & No & 0 \\
\hline 6 & No & No & No & No & No & Yes & Yes & 29 \\
\hline 16 & No & No & Yes & Yes & Yes & Yes & Yes & 71 \\
\hline 30 & Yes & Yes & Yes & Yes & Yes & Yes & Yes & 100 \\
\hline 80 & Yes & Yes & Yes & Yes & Yes & Yes & Yes & 100 \\
\hline
\end{tabular}

III: Sensitivity of the wine assessors on a random addition of higher fatty acids in wine

\begin{tabular}{|c|c|c|c|c|c|c|c|c|}
\hline \multirow{2}{*}{$\begin{array}{c}\begin{array}{c}\text { Addition } \\
{[\mathrm{mg} / \mathrm{l}]}\end{array} \\
1\end{array}$} & \multicolumn{7}{|c|}{ Sensitivity of assessors } & \multirow{2}{*}{$\begin{array}{c}\begin{array}{c}\text { Response } \\
{[\%]}\end{array} \\
0\end{array}$} \\
\hline & No & No & No & No & No & No & No & \\
\hline 3 & No & No & No & No & No & No & $\mathrm{No}$ & 0 \\
\hline 4 & No & No & No & No & No & No & No & 0 \\
\hline 6 & $\mathrm{No}$ & $\mathrm{No}$ & No & No & No & No & $\mathrm{No}$ & 0 \\
\hline 16 & No & No & No & No & Yes & Yes & Yes & 43 \\
\hline 30 & Yes & Yes & Yes & Yes & Yes & Yes & Yes & 100 \\
\hline 80 & Yes & Yes & Yes & Yes & Yes & Yes & Yes & 100 \\
\hline
\end{tabular}


mixture similar to wine or must before the end of fermentation and create film on the surface.

Recommend dosage into the fermenting media is in the prepared mixture of $1: 10000$ ( $1 \mathrm{ml}$ to 10 liters of media). Dosage into the wine is in the prepared mixture 1:20000. By observance of these concentrations is influence on organoleptic characteristics of resulting product, by a large margin, zero.

Dosage into the fermenting media causes rapidly inhibition of yeasts metabolic activity, their death and complete stopping of alcohol fermentation. Dosage into the finished wine works as a precaution against lactic acid bacteria and secondary fermentation (re-fermenting). Addition of higher fatty acids can significantly reduce the dosage of other preservatives such as sulfur dioxide and sorbic acid. This method can effectively reduce the cost of the technology involved in wines with residual sugar. Especially effective is the addition of higher fatty acids in combination with reduced dose of sulfur dioxide appears in home winemaking conditions where is not possible to use expensive operations routine used in the larger wineries (refrigeration, sterile filtration). The procedure uses a mixture of higher fatty acids reduces the labor intensity of wines with residual sugar. And according to today's appellation for sulfur dioxide reduction, especially for bio-wines, could be this mixture very effectively used.

\section{CONCLUSIONS}

This paper evaluated inhibition of alcoholic fermentation to leave residual sugar and the possibility of sulfur dioxide reduction in wine technology and wine storage. Mixture of higher saturated fatty acids $\left(\mathrm{C}_{8}-3 \mathrm{mg} / \mathrm{l}\right.$ and $\left.\mathrm{C}_{10}-6 \mathrm{mg} / \mathrm{l}\right)$ were tested. Experiments have confirmed that the concentration of viable yeasts in $1 \mathrm{ml}$ of wine for variants treated (in the end of fermentation) with a mixture of fatty acids is significantly lower (order of $10^{\circ}-10^{2}$ ) than in variants treated with sulfur dioxide alone (order of $10^{3}-10^{4}$ and more). Then was monitored the influence of fatty acids on stored wine with residual sugar. At this point a dramatically prolongation of interval to secondary fermentation (depreciation of wine) in the bottle was confirmed. Especially, the $28^{\text {th }}$ of January 2010 in case of no added and $11^{\text {th }}$ of March 2010 for additional $6 \mathrm{mg} / \mathrm{l}$ of a fatty acids mixture. Subsequently, the data fit the polynomial regression of the third degree with $\mathrm{R}^{2}=0.9988$. Finally, attention was paid to influence on the organoleptic characteristics of wine treated this way. In this case, it is possible to consider the concentration of fatty acid below $6 \mathrm{mg} / \mathrm{l}$ as no effect, i.e. below the threshold of susceptibility.

\section{SUMMARY}

This work is aimed on stopping of alcoholic fermentation to leave residual sugar and the possibility of sulfur dioxide reduction in wine technology and storage.

Mixture of higher saturated fatty acids $\left(C_{8}-3 \mathrm{mg} / \mathrm{l}\right.$ and $\left.C_{10}-6 \mathrm{mg} / \mathrm{l}\right)$ were tested. Experiments have confirmed that the concentration of viable yeasts in $1 \mathrm{ml}$ of wine for variants treated (in the end of fermentation) with a mixture of fatty acids is significantly lower (order of $10^{\circ}-10^{2}$ ) than in variants treated with sulfur dioxide alone (order of $10^{3}-10^{4}$ and more).

Especially, the $28^{\text {th }}$ of January 2010 in case of no added and $11^{\text {th }}$ of March 2010 for additional $6 \mathrm{mg} / \mathrm{l}$ of a fatty acids mixture. Subsequently, the data fit the polynomial regression of the third degree with $\mathrm{R}^{2}=0.9988$.

Then was monitored the influence of fatty acids on stored wine with residual sugar. At this point a dramatically prolongation of interval to secondary fermentation (depreciation of wine) in the bottle was confirmed.

\section{REFERENCES}

ALEXANDRE, H., MATHIEU, B. and CHARPENTIER, C., 1996: Alteration in membrane fluidity and lipid composition, and modulation of $\mathrm{H}$ + -ATPase activity in Saceharomyces cerevisiae caused by decanoic acid. Microbiology 142, 469-475.

DE FELICE, M., 1993: Free fatty acids inhibiting malolactic fermentation in wine. Note 1. Industria delle bevande, XXII, April, 126-130.

GENEIX, C., LAFON-LAFOURCADE, S. and RIBÉREAU-GAYON, P., 1983: CR Acad. Sci., serie III, 296, 943.
LAFON-LAFOURCADE, S. and RIBÉREAUGAYON, P., 1984: Developments in the microbiology of wine production. In: BUSHELL, M. E. (ed.) Progress in Industrial Microbiology, 19. Elsevier, Amsterdam, pp. 145.

LARUE, F., MURAKAMI, Y., BOIDRON, J. N. and FOHR, L., 1986: Conn. Vigne Vin, 20 (2), 87.

RIBÉREAU-GAYON, P., DUBOURDIEU, D., DONÉCHE B. and LONVAUD, A., 2006: Handbook of Enology Volume 1 The Microbiology of Wine and Vinifications 2nd Edition, 2006 John Wiley \& Sons, Ltd ISBN 0-470-01034-7. 
SÁ.-CORREIA, I., 1986: Synergistic effects of ethanol, octanoic and decanoic acids on the kinetics and the activation parameters of thermal death in Saccharomyces bayanus. Biotechnol. Bioeng. 28, 761-763.

SÁ-CORREIA, I. and VAN UDEN, N., 1983 Temperature profiles of ethanol tolerance: effects of ethanol on the minimum and the maximum temperatures for growth of the yeasts Saccharomyces cerevisiae and Kluyveromyces fragilis. Biotechnol. Bioeng. $25,1665-1667$.

VIEGAS, C. A. and SÁ-CORREIA, I., 1991: Activation of plasma membrane ATPase of Saccharomyces cerevisiae by octanoic acid. J. Gen. Microbiol. 137, 645-651.
VIEGAS, C. A. and SÁ-CORREIA, I., 1995: Toxicity of octanoic acid in Saccharomyces cerevisiae at temperatures between 8.5 and $30^{\circ} \mathrm{C}$. Enzyme Microb. Technol. 17, 826-831.

VIEGAS, C. A. and SÁ-CORREIA, I., 1997: Effects of low temperatures $\left(9-33^{\circ} \mathrm{C}\right)$ and $\mathrm{pH}(3.3-5.7)$ in the loss of Saccharomyces cerevbsiae viability by combining lethal concentrations of ethanol with octanoic and decanoic acids International Journal of Food Microbiology 34 (1997) 267-277.

VIEGAS, C. A., ROSA, M. F., SÁ-CORREIA I. and NOVAIS, J. M., 1989: Inhibition of yeast growth by octanoic and decanoic acids produced during ethanolic fermentation. Appl. Environ. Microbiol. 55, pp. 21-28. 